\title{
CULTURE AND INDIVIDUAL PERFORMANCE MANAGEMENT IN UNIVERSITY OF CAPE COAST GHANA : TOWARDS A LARGE SCALE RESEARCH AGENDA
}

\author{
George K.T. Oduro \\ University of Cambridge, U.K. \\ Geogina Y. Oduro \\ University of Westminster, U.K.
}

\begin{abstract}
Universities in Africa do not operate in a vacuum. Their success depends not only on socioeconomic and political factors but also on cultural values that influence their activities. In this article, we draw upon the case of one Ghanaian university to illustrate the extent to which cultural values that individuals bring to the workplace pose challenges to performance management. We argue that an in-depth understanding of the micro and macro cultural contexts of performance management is critical, if the University of Cape Coast can cope with current competitive maket demands. We finally put forward a proposal for an extensive research into the cultural challenges facing performance management in other African universities:
\end{abstract}

\section{Introduction}

A key coneern in university education today is how to manage the performance of its staff. Consequently, strategies for enhancing the performance management skills of academic and non-academic leaders have become crucial in discourses that focus on achieving sustainable competitive advantage. This is reflected in the theme "Performance management and control: a neglected aspect of human resource administration' (Lubwama, 2004:8) that featured prominently in the April 2004 Stellenbosch, South Africa, Conference of the Association of Commonwealth Universities ( $A C U$ ). Similarly, performance management has become central to the institutional and professional development strategies of African public universities. In Ghana, as an example, the University of Cape Coast's corporate strategy adopts an 'action-driven means of measuring corporate performance' as a means by which managers at all levels could manage the implementation of action plans (UCC Corporate Strategy, 2003:12 \& 13). Similarly, the Make "re University has put in place performance management tools such as 'departmental plans and individual work plans' as strategies for enhancing performance (Lubwama).

\section{The Context}

Public universities" increasing pursuit of performance management strategies is attributable to pressures emanating from changes in government policies; high public expectations and the need to meet international standards of operation (Mittal, 2004). Moreover the mushrooming of private universitics in Africa does not only pose competitive threat to public universities but has more importantly necessitated the transformation of how they operate. The number of private universities in Africa that stood at about 27 in 1990 (Sawyerr, 1999), has now risen to nearly 100. Ghana, for instance, which had no private university in 1990, now has almost 10 private universities as against 5 public universities. Activities of these private universities are increasingly attracting (more) interest of public compared to government-funded universities. A major challenge facing public universities therefore lies in how they could 

attract and retain quality staff and effectively utilise their skills and knowledge towards meeting market demands.

Coping with these challenges we believe, has implications for the way public universities manage culture and individual performanee. Increasingly, it has been acknowledged that a business or service organisation's ability to outperform its competitors party depends on its culture. A study of the state of human resources mamagement in one University in Ghana, the University of Cape Cost (Oduro, G. Y. (2004), illustrates the extent to which) cultural values that individuals bring to the workplace pose challenge to the university's personnel and performance managenent. But will this be true for olher universities across Africa? Although there is a plethora of literature on various aspects of challenges ficing African Universities yet little attention has been given to miero and macro cultural issues that affect individual performance management.

The departure of our article lies in its focus on the cultural context of individual performance manigement. We draw upon Oduro's study and inemational literature in exploning the relationship between organisational culture and organisational perfomance and discuss its implications for the university. As a way of setting an agenda for future research, we argue that. firstly. unclerstanding how African universities manage individual performance in the face of the viriety of challenges facing them cannot be complete uniess we explore in-depth the underpinning cultural contexts. Secondly, effective performance management in African Universities does not only call for a change in their bureaucratie structure but also poses the challenge of changing subcultures of individuals and groups within the universities. It also calls for a balance between the university's culture and that of the larger society's value, beliefs and practices to ensure that it meets the changing demands successfully. As Thornhill et al (2000:3) explains. alterations to the strategic direction and activity of an organisation may necessitate changes to its structures, systems, culture, managerial approach and technology.

\section{The Study}

The empirical basis of our article derives from Oduro's qualitative case study (Oduro, 2004) that sought to explore the perception of authorities of the University of Cape Coast on how cultural values and practices infuence human resources management in the institution. The rescarcher adopled a yualitative approach because of the sensitive nature of the study. As Maykut and Morchous (1994) observe, qualitative research values context sensitivity that understands a phenomenon within a particular situation and enviromment. The study involved six people who were directly connected with management issues within the vice Chancellor's office, the Registar's office, the Paculties and the Academic departments of the university. The participants were purposively chosen for the study. Purposive sampling, according to Kane (1995), does not involve randomly selected samples in that participants are deliberately chosen because of some qualities that interest the researcher. In the light of the smallish number of the participants (6), the data were collected through interviews.

\section{Defining Organisational Culture and Organisational Performance}

Comprehending the relationship between organisational culture and organisational performance depends on how one conceptualises the two terms. Within the context of an organisation such as the university, culture is said to represent 'an interdependent set of values and ways of behaving that are common in a community and that tend to perpetuate themselves. sometimes over long periods of time' (Kotter and Hesket, 1992. cited in Brown, 1995:141). For Drennan (1992:3), it may refer to 'how things are done around here. It is what is typical of the organisation, the habits, the prevailing attitudes, the grown-up pattern of accepted and expected behaviour (Brown 1998:26). On the whole, writers appear to agret that culture is a "shared' and a 'learned" phenomenon. 
In contrast, Organisational performance may be understood in terms of an organsation's: eflectiveness, a concept that is iscif relative in meaning. As Brown argues. 'each stakeholdes group will have its own set of preferences for measuring organisational eflectiveness if. 210). While some commentators appear to agree that performance can be understood in terms of how high or how low an orgamisation pertorms economically, others fook at it in lerms of "an organisation's ability to extend its control over its environment. Reeves ex al (2002) identifies two perspectives of conceplualising performance mankegment within the context of education: the manageriai perspective and the professional perspective.

From the manageriaj perspeclive, performance mangement is seen in terms of 'specific set of practices developed to control the behaviour of individuals through formal appraisal systems and Performance-related Pay (PRP)" (p.4) Put in words of Armstrong and Baron (1998), it involves a strategic and integrated approach to delivering sustained success 10 organisations by improving the performance of people who work in them and by developing the capabilities of teams and individual contributors' $(p .7)$. As a professional phenomenon, performance management is detined in terms of individual professional worker's self-directed efforts towards the provision of quality services to the organisation"s clients. In this sense. the responsibility of managing performance is located in the individual professional practitioner instead of managers. This is beciuse, by being a professional, a person understands and acts upon the obligation to carry out the tasks effectively for the benelit of the client' (Reeves et al, p.5). Defining performance management this way connotes a sense of duty among individuals that pervades obligations, self-regulation in interests of elient, maintain and enbance expertise and self-monitoring of performance' (ibid. p.6).

In the context of this anticle, however, we conceptualise organisational performance in terms of the level at which the university as an organisation, through an aggregation of the pettormance of individuals, is able to accomplish its mission compared to others on the competitive market. It has been acknowledged that micro and macro socio-economic demands on universities have necessitated changes in their mission and the traditional ivory towered roles of leaching and research. They are now expected to move beyond these traditional roles and contribute more to the development of the nations in which they operate. Specilically, they are required to prepare their nations to become more competitive in matters related to etadication of ignorance, the tight against poverty, hunger and disease, the promotion of democracy, good political and economic governance, human rights, peace, security and stability, and sustamible development (Njeuma, 2003). In sum. African universities are at present reçuired to 'be in the forefront of research, education and action' in helping Africa find lasting solutions to these perennial problems.

\section{Relationship between Culture and Organisational Performance}

Theoretically, writers appear to agree that thew is a relationship between culture and organisational performance. Hampden-Turmer (1990) as an example suggests that it is the culture of an organisation that 'governs the way a company processes information, its internal relations and its vatues' and also defines proper behaviour codes and bonds. "motivates individuals and asserts solutions where there is ambiguity (p.11). Similarly..

Towers (1996) cite Dill (1950) to have argued that the values, beliefs, norms and ideals that are embedded in a culture affects strategies of organisations. Empirically, Lorsch $(1986$. cited by Brown 1998, p. $213 \& 214$, in a study involving twelve successful companies found that all of them "had a culture which supported the strategy they pursued". In this light. as Brown suggests, it is now increasingly believed that organisational culture is crucial in our understanding of the successes and failures of organisations. The extent to which culture influences management, however, differs among nations (Hofstedc, 1997). 
Table 1: Hotstede's four dimensions of national cultural differences

\begin{tabular}{|c|c|}
\hline DIMENSION & CONTENT \\
\hline Power & $\begin{array}{l}\text { The extent to which the less powerful members of organisations within it } \\
\text { country expect and accept that power is distributed unequally. In high } \\
\text { power distance nations, inequalities among people are considered } \\
\text { desirable and here is greater reliance of the less powerful on those who } \\
\text { hold power. In contrast inequalities among people tend to be minised } \\
\text { in low power distance nations and decentralised activities are more } \\
\text { pronounced. Subordinates expect to be consulted by superiors, and } \\
\text { privileges and status symbols are less evident. }\end{array}$ \\
\hline Individualism/collectivism & $\begin{array}{l}\text { Pertatins to the extent to which individual independence or social } \\
\text { cohesion dominates. Individualistic societies have loose social ties } \\
\text { between individuals. Individuals are supposed to bake care of } \\
\text { themselves and possibly their immediate lamily. Here contracts with } \\
\text { employers are based on mutual advantages and hiring and promotion } \\
\text { decisions are supposed to be based on skills and rules. }\end{array}$ \\
\hline Masculinity/femininity & $\begin{array}{l}\text { Refers to the extent to which social gender roles are elearly distinci. In } \\
\text { high masculine societies, social gender roles are clearly distinct and men } \\
\text { supposed to be assertive, tough and focus on material success while } \\
\text { women are expected to be modest, tender and concened with the quality } \\
\text { of life. In high femininity societies, both men and women are expected } \\
\text { to be modest, tender and concerned with the quality of life. }\end{array}$ \\
\hline Uncerlainty avoidance & $\begin{array}{l}\text { Refers to the extent to which members of a culture feel threalened by } \\
\text { uncertain situations. Where societies have weak uncertanty avoidance, } \\
\text { there is greater tolerance of ambiguous situation, people are } \\
\text { hardworking only when they need to be, precision and punctuality have } \\
\text { to be loarnt, people are comfortable with deviant and innovative ideas } \\
\text { and behaviour, and are motivated by achievenent, and belongingness. } \\
\text { In strong uncertainty avoidance societies, there is fear ol ambiguous } \\
\text { situations, a feeling that time is moncy and there is an emotional need to } \\
\text { be busy, precision and punctuality come naturally, novelty is resisted } \\
\text { and people are motivated by security, and by esteem and belongingness. }\end{array}$ \\
\hline
\end{tabular}

Although the literature is cxplicitly on the relationship between culture and performance in organisations, determining the actual level of culture's influence on organisational performance is problematic. While some whiters view culture as an asser to organisational performance, others see it as a liability. Central to this problem is, firstly, the assumption that culture can be either 'good' or 'bad' and that it is only when an organisational culture is considered good that it can enhance organisational performance. Considering that the meaning of 'culture' is by itself relative and volates a universally acceptable definition, we find the 'good' and 'bad'; dichotomy of culture complicated. This is because, as Jeffcutt (1993) observes. 'most aspects of culture are difficult to designatc ats elcarly good or bad Coniradictory interests - those of professions, divisions, classes, consumers. environmentalists, owners, top management, etc. may produce different views on what is good. important and appropriated (cited by Alvesson, 2002:4) argues, it would be strange to find a company where top management, middle management, clerical personucl, foor workers ctcerera shared norns and acted upon them in similar wilys' Morcover it is not easy 'to try to isolate norms and wahes shared throughout the organisation (or any other unit) as a separate calusal factor in work performance because norms and values are largely associated with different groups to different degrees and have: different content'.

These problems notwithstanding, research evidence suggests strongly that culture influences, and can be engineered to enhance organisational performance. Mannion el al (2002). 
Inference from Mannion et al's observation and the case of the Universily of Cape Coast. as we present later, suggests that an organisation's culture does not necessarily lead to its: ssuccess. It may either enhance or retard performance in organisations. This is reflected in Sathe's (1985, eited by Brown. 1998) argument that shared beliets, values and as mptions can interfere with the needs of the business and lead people 10 thank and act in commercially and/or ethically inappropriate ways'.

\section{Cultural Values and Performance Management: the case of UCC}

\section{Maintaining relationships and organisational ethics}

A common feature across the discourses of all the respondents in the study suggests a dilemma as authorities of UCC find themselves entangled between commitment to cultural expectations and management governed by organisational ethics. Underpinning this dilemma is the issue of relationship. For the purpose of maintaining good relations with their colleagues, some heads tended to compromise their performance managenent principles this is reflected in the statement: the issue of communal living is very importan Sometinus the nature of relationshap is such that it becomes diflicult to apply the rules as mationally as we have to (An academic head).

This challenge is critical in matters relating to employee's use of official lime. Some peopic in management, according to the data, found it difficult to ensure that employees used ofticial time judiciously because it sometimes strains relationships. Others elucidated that although some junior staff and some departments of the university do not perform well, it was not easy disciplining them because they might be the son, daughter or spouse of a colleague or at lecturer'. As a result, the endency is for some heads to compromise their performance management principles for the mere purpose of maintaining good rejations with their colleagues. One respondent illuminated this as follows:

There are some workers who rally is not pulling their weight. But because of tradition and cultural implications, authorities hardly get the moral conarge to dismiss such people. This is where the culural thing comes in. It needs a lot of courage, for amybody to come and say this person should go. (th academic head).

Another retation-focused aspect of Ghanaian cultural practices that posed a challenge to performance management in the university relates to bereavement. This is retlected in the following remark:

Within African institutions, the isste of communal iving is very importam. When something happens to an individuat everybody is cxpected to rally around him. So as a uni ersity, we tend to take on cortain practices, which in other universinios mas not be scen, as important. We all rally around to support this person in the time of his bereavement (An administrative head).

This finding corroborates Fashoyin's (2000) observation that organisations in Africa tend to place greater value on care for employees thar' profitability or markes shares', thus makine business objectives secondary to welfare issues. It also strengthens Dehah's observation (Debrah, 2000) that cultural factors related to relationships such as sentiments and passion tend to post challenges to management in hanaian organisations. Some respondents saw the communal support for bereaved workers as a liability in the pursuit of the university's performances largets. Disruption of the day's work and the frequent absences mate by bereaved individuals were some adverse effects: At times the absences becone too fiecuent 
but the situation is such that it becomes difficult to apply the rules ats rationally as we have to. So we use our discretion,' (An academic head).

Using the discretionary decision poses further challenge: "it creates a problem if you are not fair'. A non-academic head saw the university's fullilment of this cultural expectation as a drain on the university's finances. The negative aspect of it is that we spend so much money moving vehicles from one place 10 another'. In contrast, an academic head saw the practice as an asset for performance management: 'what we get from this is great. It makes them (workers) have a sense or feeling that they belong to an organisation that cares. It makes them go an extra mile when they are asked to.

Further, over-adherence 10 gender stereotyping emerged as a souree of chalfenge. One respondent argued that sticking too much to cultural expectations from women had prevented many women on his staff from taking advantage of self-improvement oppotunities in the university:

\section{Let's take women for example. Some of them are so committed to cullural expectations of their family life that if you suggest a period of training that may take her awoy from home for sometime or that may keep her away from the fomily at cerfain times of the year she is not going to do it. (...)}

The foregoing trends demonstrate how entrenched values attached to aspects of cultural practices can shape the way managers do lhings. As Brown (1999:26) articulates, values are intimately connected with moral and ethical codes, and determine what people think ought to be done' and they have "an association with attitudes that individuals put up at the work place'. Establishing healthy relations with workers, as we find in the case of UCC, is undoubtedly a cucial factor in the process of achieving organisational goals. It is even more crucial when we consider that the University, at present grapples with increasing market competition posed by the emergence of private universities, however. it becomes problematic when the fear of breaking relationships becomes a determining criterion for managing individual performance in the university.

\section{Cultural expectations of managers towards subordinates}

The statement, as a head, people see me more or less ats their father" commonly characterised how some respondents think university workers perceive people in leadership positions at various levels of the university's hierarchy. This is commutative of the existence of a high power distance' between the university's leaders and workers. As Hofstede (1997) explains cultures that are characterised by 'high power distance' tend to accept inequalities among people with less power relying on those who hold power. Workers" perception of the heald as a "father", as shown in the case of the UCC, goes with expectations: "when they come to me they think I have the magic and; whatever the problem they come with, 1 must be able to provide a +solution' (An academic administrator). Within the Ghanaian context a "father" is considered as the provider of al] that his family needs to make the family home fively for which he must be obeyed without questioning. In this Iight the Departmental Head, Dean, Registrar or the Vice Chancellor - viewed as a "father" is obeyed for his/her authority and power. A parallel of this is found in Adlers' (1997) study in which he found that in similar high distance countries, such as the Philippines. Venezuela, and India, employees did their work in a particular way not because they believed that it is the best way to do it, but because their boss wints it done that way.

\section{Implications for individual performance management}

The themes discussed in the preceding sections have leadersinip implications for performance management in the UCC. They raise a question as to what type of leadership the vice- 
chancery, academic headship, registry and all others involved in managng the university's resources need to enabic them change cultural attitudes that tend to affect pertormance.

Two approaches that energe from this study are of interest here. The first is an approach that stresses 'strict adherence to laid down rules and regulations and the use of countries with little concem for what happens to relationships (a non-academic head). This suggests a more authoritatian feadership approach, which according to Blase and Anderson (1995), involves exercising control through formal structures and the enforcement of policies and rules. In this sense, Ileads of Unis, Deans, the Registrar and others with mantagenent responsibilities are required to exert much power over employees and enforce workers compliance with the university's work ethics. 'This is reflected in the comment "we" are not here to satisfy people's interests, we're here to satisfy first and foremost the organisationa interest' (a nonacademic head). Denotative in this quotation, is a performance management approach in which managers distance themselves from workers as a way of controlling the influence of familiarity. As Henry et al., (1999) explains, lechniques of steering from il distance are usually adopted through the means of regulation, incentive and sanctions to make autonomous individuals and guasi-governmental and non-governmental institutions such as universities belave in ways consistent with their policy objectives.

Ghana, being a country where relationships are characterised by high power distance, one may be ampted to agree that an authoritarian approach will work. Inference from the data. coupled with our own personal experiences, however, suggest that changing entrenched cultural values and traditions to which individuals ascribe through authorities managenent approaches is problematic. It could increase employer-employee contlicts that have often affected academic calendars of the university. This is because of the complex micro-politics involved. The university comprises groups of different interest; some of whom are likely to resist top-down initiated cultural changes. This is reflected in a case narrated by one of the respondents.

In the late 1980 s, according to the respondent, UCC experienced a series of strikes by workers resisting cultural changes that its new administration attempted to introduce. Slackness in the judicious use of official time had become so entrenched in the culture of the institution that workers had internalised it as part of their privileges. Some workers tended to use official time for transacting private businesses with impunity, and received salary for no apparent work done. Attempts by the administration to change this aspect of the institution's culture towards enhancing performance therefore countered very disruptive work demonstrations.

The second approach stresses a leadership strategy that seeks to use trust, motivation and collaboration as tools for developing desired attitudinal quatities in workers. As acadenic head's statement exemplifies this, "we want a university environment where there is cordially, where both students and staff trust each other and work logether to achieve the best in the university'. Trust, according to Elmore (2003:17) is:

A compound of respect, listening to and valuing the wews of others, personal regard, intimate and sustained personal relationships that undergird professional relationships: competence. the capacity to produce desired results in relationships with othors; and personal integrits: truthfulness and honesty in relationships.

Employing this strategy will require a democratic leadership approach to the unjversity's human resources management. Burns (1978) explains that this situation crises when members of staff raise one another to higher levels of motivation in order to bring about unity, collective responsibility and mutual trust.

it brings about successful utilisation of democratic management strategies by the university's authorities will, however, require deeper changes in the university's bureaucratic structure. 
This is because, firstly, power relations in the aniversity is structured along Hofstede's high power distance. Secondly, it has a hierarchical tradition whereby the head is viewed as at 'father' whose atuthority subordinates respect, and on whom workers depend for resolving welfare-gelated maters. It will therefore require that boil those in leadership positions and workers re-orientate their minds towards power and authority and be prepared to operate in a more open environment where, as Blasé and Andershon (1995) observe, 'virtually anything can be questioned or challenged without fear'. As part of its strategic plan towards developing appropriate working attitude among workers, UCC has introduced regular durbars with staff to listen to their problens, to listen to their problems, discuss with them how best we can motivate them and talk to them about work ethics'. Yet, it is our argument that these durbars will be a mere tormality unless, first, the autherities become mindful of the politics of self-interest that could characterise opinions erred by individuals during such durbars.

The politics of self-interest within the university, which its authorities need to strategically manage, is a complex one. Iis mature is reflected in Hodgkinson's (1991) observation that organisational manigement operates in an arena of conflicting forces, where the interplay and blending of personal attributes and organisational rate expectitions vary widely.

As illustrated in the figure 1 below, these interests derive from values that individuals bring to the organisation, value orientation of the individual's immediate work group, the formal values of the organisation as expressed in the overt and covert goals, work ethics and reward policies, purposes and organisational culture of the organisation. The interest also derives from the values of the immediate explicit and implicit values of the national culture. These complex interests need to be considered if cultural values that affect human resources management in the university can be effectively managed.

Gaining an understanding of the eulture and sub-culture of the environment, the informal organisation and the individuats who compose th organisation, according to Hodgkinson, is necessary for managers to make adaptive organisational responses. In this context, we argue that awareness of the nature of cultural values upheld by individuals and groups within the university and those of the larger society can help university leadership to utilise appropriate impression manigement techniques to win the support of individual workers towards optimum commitment and performance. Impression management has been identified as a viable tool by which managers 'justify an event" or "enhance the perception of the actor in the eyes for his or her audience'. It deals with how mangers 'manage verbal and nonverbal communication to convey a positive image of self to others (Rahim \& Buntzman, quoted in Giacalone \& Rossenfeld, 1991:158). 


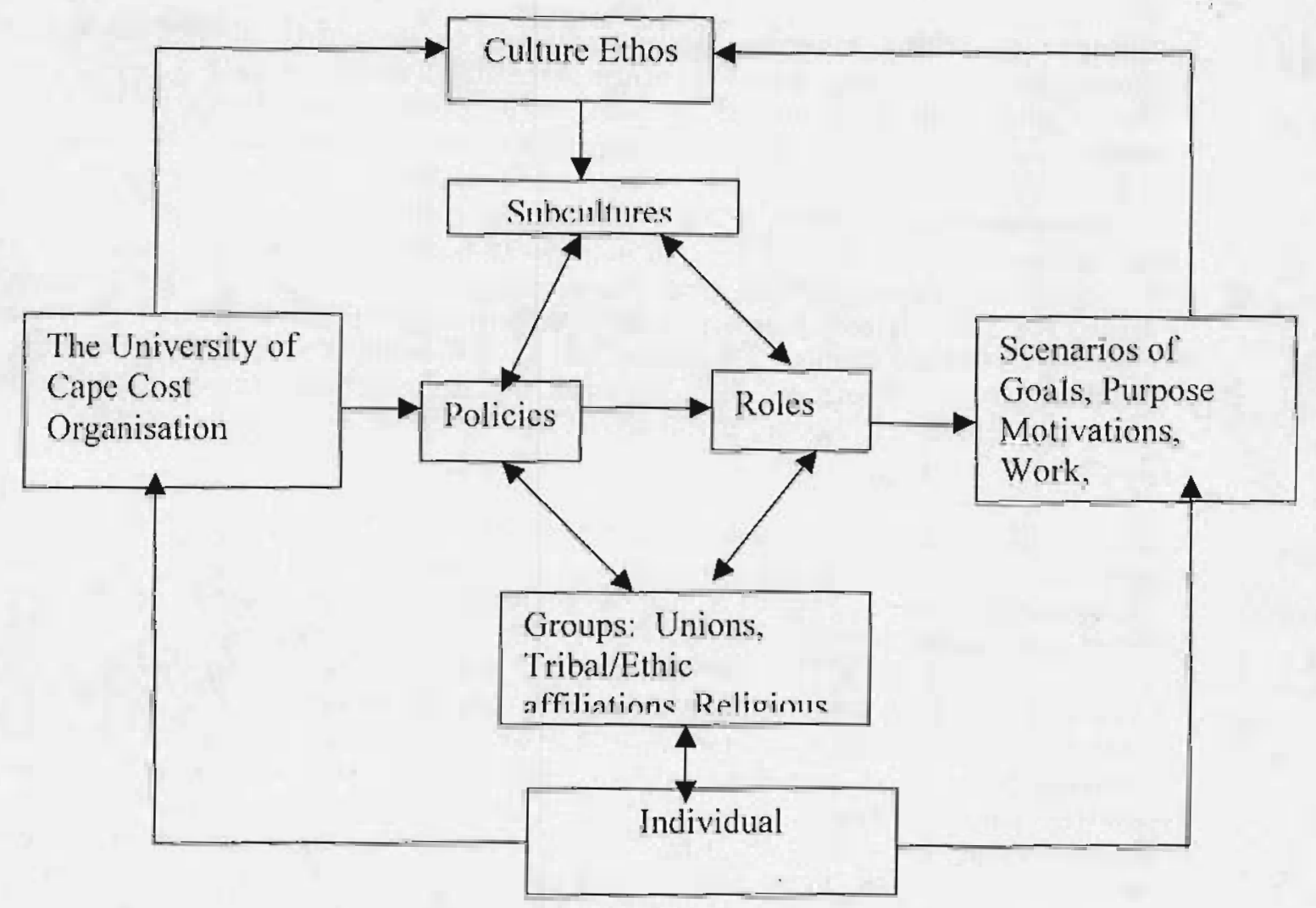

Fig 1. Complexities of interests related to the management of culture. Adopted and modified from Hodgkinson, (1991).

\section{Creating the desired Culture for enhancing individual performance.}

Creating a culture of excellent performance in the university is not easy. Vice chancellors, registrars, deans and departmental heads and all those who have the responsibility for managing individual performance therefore have a Herculean task in terms of helping people to develop the right attitude for achieving the university's goals. To succeed, performance managers need to, firstly, have clear knowledge and understanding of the content of the university's corporate strategy and the determination to implement the change (Brown, p. 219). Secondly, they must have an in-depth knowledge on the existing and the desired individual performance cultures; exhibit confidence in managing performance and be prepared to delegate part of the authority associated with their positions to subordinates. As positions to subordinates. As Steward (2004) exhorts, every executive who desires to create a culture of excellence in his/her organisation, must be willing to pay a price.

Also crucial in any cultural engineering effort is the creation of a non-threatening atmosphere that encourages stakeholders at all levels of the university to contribute towards the change initiative. Active involvement and participation of members of an organisation, according to Denisori, "create a sense of ownership and responsibility" and leads to a greater employec commitment to the organisation, leading to performance enhancement' (cited by Brown, p. 227). Academic and non-akademic staff's support for a university's cultural engincering will be more meaningful when deans, heads of departments and units who are directly involved in managing individual performance are able to identify most influential workers and actively involve them in decision- 
making (Stewart, 2004). We need to re-learn old lessons about how culture ties people together and give meaning and purpose to their day to day lives. (Parker, 2000:12-13).

The foregoing implies that the performance management of the university need s to be driven by a human resources model, which according to Torrington \& Hall (1998) recognises people as 'the key to competitive advantage' (p. 28). Butler (1988) identifies the buman resources model as a shift 'from human resources as the implementers of strategy to human resources as a driving force in the formulation of stategy' (in Torrington \& Hall, p. 28). Central to this model is effective communication. As Buckingham and Coffman (1999) in their book, Break All the Rules, "... helping an employee excel lies in the details; the details of his particular recognition needs, of his relationship needs, of his goals, and of his talents/non-talents". It is our opinion that with a buman resources driven model, the university will, firstly, be able to facilitate its strategies for bridging the gap between the cultural values that individuals bring to the work place and the university's corporate plans. Secondly, it will be able to work out more positive reconciliation strategies between the university's culture and that of the iarger society.

\section{Summary \\ Our discussion so far suggests a strong link between culture and performance management. Cultural values that individuals and groups bring to the unjersity can be both an asset and a liability to individual performance management. These cultures can, however, be engineered to enhance performance. For performance to be enhanced, heads of both academic and non- academic departments need to understand their departments and the university better in terms of values and practices that shape work practices. To get a broader picture of the cultural problems facing other African universities, however requires a further exploration of the emerging issues on a wider scale. For example, will the observation that cultural role expectations tend to undermine efforts of UCC towards developing female workers be true in all the other universitjes? Do other universities in Africa experience the same cultural challenges as found in the case of UCC? These may or may not be the case in other public universities in Africa.}

\section{A Research Proposal/Recommendation}

In this article we have explored some challenges that cultural values pose to the management of individual performance in one African University - the University of Cape Coast. The issues emerging from the article sets a scene for further research into the effects of cultural values on performance management. We hypothesise that eflective management of individual performance within African universities depends on the extent to which university authorities understand the micro and macro cultural values within which their institutions operate. It also requires an indepth understanding of how university authorities conceptualise indicators for performance and the extent to which the university promotes the culture of shared leadership for learning. These, as we have outlined below depend on a range of factors:

a. Constructions of the modern role of the university

- Administrator's beliefs and role expectations of the university.

- Academics' beliefs and role expectations of the university.

- Non-academics" beliefs and role expectations of the university.

- Students' belief's and role expectations of the university.

b. Change, Human resources and Performance management

- Human resources as implementers of change strategy.

- Human resources as triggers in policy formulation.

c. Cultural dimensions of university performance 
- Calture ethos of the university.

- Culture of the larger society.

- Sub-cultures of individuals and groups.

\section{d. Leadership and management}

We propose that these four factors should form the foundation for a large scale researcli project that will shed more light on the extent to which micro and macro culture values pose challenges to the management of individual performance in African universities. It should also provide the empirical bases for identifying the best practices for enhancing performance througin cultura] engineering in African universities. The proposed research would be a collaborative project focusing on universities in the Western, Eastern and Southern regions of Africa, It will, however. draw upon literature from other countries, especially in England, China and India.

Tentatively, the rescarch would aim to:

1. Explore the cultural challenges facing performance management in African Universities.

2. Examine the extent to which existing performance management styles either promote or inhibit the implementation of corporate strategies of universities.

3. Identify and evaluate how those in leadership positions at various levels of universities align cultural values that individuals carry along to the university with the university's culture ethos.

4. Examine the wider international university performance management policy context and thinking about cultural influences through agencies such as the Association of Commonwealth Universities (ACU) and the British Educational Leadership. Management and $\Lambda$ dministration Society (BELMAS).

5. Draw out key messages for university leadership.

\section{Conclusion}

We propose that an in-depth understanding of the micro and macro cultural contexts of performance management in $A$ frican universities is critical, if the current numerous national and international-sponsored university improvement initiatives are to achieve their desired goals. The time has come some extensive rescarch that will empirically inform university leaders and their international partners about the effects of African cultural values on change initiatives and the leadership styles needed for coping with cultural challenges. We need a cultural-focused empirical evidence, which may be drawn on for the benefit of performance management, professional development, capacity building and networking.

\section{References}

Addler, N.I. (1997). International dimensions of organisational behaviour. Ohio: South-Westem College Publishing. Publications.

Alversson, M. (2002). Understanding orgamisational culture. Lonton: Sage

Armstrong, M. and Baroli, A. (1998). Performance management: The new realities. London: IPD. 
Blasé \& Anderson (1995). \& Anderson (1995). The micro politics of educational leadership: from control to empowermen. New York: Teachers' Press.

Buckingham, M. and Coffman, C. (1999). First, break all the rules: what the world's greatest manages do differently. Amazon: COM

Brown, A. (1995, 1998). Organisational vulture .Englewood Cliffs N. J.: Prentice Hall.

Burns, J. M. (1978). Leadership. London: Harper \& Row, Publishers.

Debrah, UY. A. (2000). 'Management in Ghana'. In Warner, M. (ed). Management in emerging countries. London: Business Press.

Elmore, R. F. (2000). Building a new structure for school leadership. Washington. D.C.: The Albert Shanker Institute.

Fashoyin, T. (2000). 'Managing in Africa', in Warner (Ed.). Management in Emerging Countries. London: Business Press.

Giacalone, R. A. \& Rosenfield (eds, 1991). Applied impression management. London: Sage Publication.

Goffee, Rob and Jones, Gareth (1996). "What holds the modern company logether".

Hampden-Turner, C. (1990). Charing the corporate mind: from dilemma to strategy. Oxford: Basil Blackwell.

Henry, M. Lingard, B. Rizvi, F. and Taylor, S. (1999). 'Working withragainst globalisation in education, Journal of Education Policy, 14(1): 85-97/

Hodgkinson, C. (1991). Educational leadership: the moral art. New York: State University of New York Press.

Hofstede, G. (1997). Cultures and organisations. Maidenhead: McGraw Hill

Kane, E. (1995). Seeing for yourself Research handbook. Washington D.C.: World Bank.

Kanumgo, R. N. \& Jaegar, A.M. (1990.). (eds.). Management in developing countries. London and New York: Routledge.

Lubwama, J. (2004). 'Performance management and control: a neglected aspects of human resource administration'. In The Capacity. London: Association of Commonwealth Universities. June 2004 , No. 2 p. $8 \& 9$.

Mannion R. Davies H. \& Marshall M. (2002). Cultures for performance in health care: evidence on the relationships between organisational culnure and organisational performance in the NHS. York: Centre for Health Economic. 
Maykut, P. \& Morelsouse, R. (1994). Begiming qualitative research, A philosophic and practical gaide. London: The Faimer Press.

Mittal. P. (2004). Training of Educational Administrators. A paper presented to the ACU conference held in Stellenbosch, South Africa.

Njezma, D. L. (2003). The contribution of higher education to nationat and regional development. A presentation made at the 2003 ACU general conference.

Queens University. Belfast, Northern Ireland.

Oduro G. Y. (2004), "The cultural challenges facing human resource management in Ghanaian universities: a case study of the university of Cape Cost. An unpublished dissertation submitted in the University of Westminster.

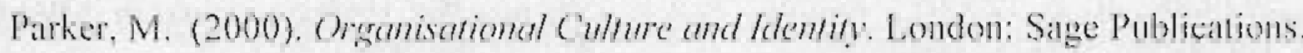

Reces, 1. Forde, C. O'Brien, J. Smith, P. \& Tomlinson. H. (1001). Performane? managemen in educution. Improving practice. London: Sage.

Sawyerr, A. (1999). 'Does African really need her universifies?' CORDESRIA Bullein. Nos. 3 \& $4: 20-25$

Stewart, K.L.. (2004). 'Creating a culture of excellence. Henty practical strategies for"

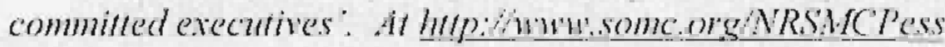
Unit.

The University of Cape Coast (2003). Corporate strategy. Cape Coast: UCC Publication

Thomhill, A. (2000). Managing change. A Human resource strategy approach. London: Pearson.

Towers, B. (1996). (ed.). Human resource management in Action. The Handbook of Humam Resounce Manugement. $2^{\text {ml }}$ ed. London:: Blackwell Pub. Lid. Author

University of Cape Coast (1991). Statutes of the University of cape Coast. Cape Coast:

University of Cape Coast (2003). Administrative Manual. UCC Cape Coast: author

Dr. George K. T. Oduro is a research associate at Cambridge University. His research interests lie in the cultural and political dimensions of school leadership, school leadership for peace building and social cohesion and the professional development for head-teachers in Africa. He worked with Prof. John MacBeeath on some consultancy programmes including Recruitment and Retention of Head-teachers in England and Teacher Self Evaluation. His Doctoral Dissertation submitted to Cambridge University won the $2^{\text {nd }}$ Price for the Britisi Educational Leadership, Management and Administration Society (BELMAS) 2004 BEST price Award Please address iuture cortespondence to: The institute for Educational Planning and Administration (IEPA), University of Cape Coast, Cape Coast, Ghana. (e-mail:gkto2@yahoo.co.uk). 
Mrs. Georgina Oduro is a graduate student at the University of Westminster. U.K. Her research interest is in Educational Administration. For future correspondence, contact. Faculty of Education, University of Cape Coast, Cape Coast Ghana. (e-mail: gkto2@yahoo.co.uk) 